\title{
The Effect of Convenience and Trust to Purchase Decision and Its Impact to Customer Satisfaction
}

\author{
Ismulyana Djan*, Siti Rubbiah Adawiyyah \\ Email address: \\ ismulyanadjan@yahoo.com (I. Djan), sitirubbiah.0107@gmail.com (S. R. Adawiyyah) \\ ${ }^{*}$ Corresponding author
}

Department of Management, Faculty of Economics and Business, University of Binaniaga Indonesia, Bogor, Indonesia

\section{To cite this article:}

Ismulyana Djan, Siti Rubbiah Adawiyyah. The Effect of Convenience and Trust to Purchase Decision and Its Impact to Customer Satisfaction. International Journal of Business and Economics Research. Vol. 9, No. 4, 2020, pp. 263-269. doi: 10.11648/j.ijber.20200904.23

Received: July 25, 2020; Accepted: August 5, 2020; Published: August 19, 2020

\begin{abstract}
The research objective is to determine the purchase decisions and customer satisfaction that are directly affected by onvenience and Trust, Customer Satisfaction that is directly affected by Purchase Decisions, and Customer Satisfaction that is indirectly affected by Convenience and Trust through Purchase Decisions. This research uses quantitative approach by collecting data through questionnaires. Population in this research are Shopee users in Bogor. Retrieval sample uses purposive sampling method with criteria of at least has purchased one time of something in Shopee Marketplace. Starting with the samples of 203 respondents and using SEM (Structural Equation Modeling) with outlier test, normality test, construct reliability test, multi collinearity test, singularity test and discriminant validity test. The results of all tests that have been done get results in accordance with the conditions set in this study. Research indicates that there is a direct positive influence of Convenience toward the purchase decisions $\left(\gamma_{11}=0,743\right)$, Trust toward the customer satisfaction $\left(\gamma_{22}=0,317\right)$, and purchase decisions toward customer satisfaction $\left(\beta_{21}=0,554\right)$. There is indirect positive influence of Convenience toward Customer Satisfaction through Purchase Decisions $\left(\beta_{21}+\gamma_{11}=0,412\right)$. Moreover there is not any effect of Trust to the purchase decisions, Convenience to the customer satisfaction, and Trust to Customer Satisfaction through purchase decisions.
\end{abstract}

Keywords: Convenience, Trust, Purchase Decision, Customer Satisfaction

\section{Introduction}

Result of the survey done by the Association of Internet Provider of Indonesia (APJII) in 2018 described that $60 \%$ of the people in Indonesia had been using internet. However, only $11.6 \%$ of the people in Indonesia had been using internet for shopping. Nevertheless, society in Indonesia are still using less the benefit of technology related to online shopping.

Most of internet users who are not in the position to do online purchasing or to become online shopper due to some reasons that have made the people reluctant to dealing with online purchasing. Shopping categories offered are still limited, the buyer cannot see or try it directly, lack of communication, some issues happened on some online application such as hacking consumer account, goods purchased are not suitable, lack of education, complicated payment system, limited delivery goods distribution, a lot of negative perception from the consumers, quality of the product, and uncertain time of receiving of the goods is quite taking time after the payment done which have made the people do not like picking online shopping.

It is unbelievable because, the instruments to shop online are quite sufficient and considered safe in Indonesia. One of famous online shopping application is Shopee. Shopee is a marketplace online established by Chris Feng in Singapore in 2015. And on December 2015, Shopee was legalized under PT Shopee International Indonesia. Since the beginning of Shopee introduction, it has received a lot of good feedbacks from the people of Indonesia. As it is a subsidiary of SEA Group, Shopee Indonesia has received full financial support from SEA Group. Having a vision 'to become Number one of C2C of Mobile Marketplace in South East Asia", Shopee users had reached 34.28 million people in 2018 and $95.32 \%$ was from Indonesia (Source, SimilarWeb). 


\section{Literature Review}

\subsection{Purchase Decision}

Mujiyana \& Elissa [14] described that a decision is the way how to choose two or more the alternative selections. The prerequisite to make a decision is depending on alternative selection or two or more selections offered.

Kotler [10] described that consumer decision is about picking the brands stated on selection criteria of the consumer and the intention to buy the brand the consumer likes.

According to Thomson written on Permatasari [15], purchase decision is an effort or behavior appeared as the response to an object. Thomson has defined 4 indicators affecting purchase decision containing of (a) need: customer has purchased a product, because the product offered is in line with his requirement and easy to find the product required. (b) benefit: the product purchased is really giving benefit to the customer. (c) proper product purchased: price of the product is complying with the quality of the customer requirement. (d) repeat purchase: a circumstance that the consumers are satisfied with the previous transaction and has made them do repeat transaction in the future.

\subsection{Customer Satisfaction}

According to Kotler [10] consumer satisfaction is a state when a consumer has satisfied receiving the goods, because the product received is just meeting the expectation of the customer.

According to Engged written on Djan \& Burhanudin [5]. Satisfaction is after sales evaluation compliance when an alternative goods being chosen at least has given the same result as expected or beyond the customer expectation, but dissatisfaction is when the product received does not meet the customer expectation.

Tjiptono [17] consumer satisfaction is the extent to which the customer has been comparing the actual the product/service received with his expectation.

According to Johnson and Rosenbloom written on Kurniawati and Purniawan [11], main indicators of the customers who like online shop mostly are indicated by on At-checkout satisfaction and After-delivery satisfaction which is within overall satisfaction. At-checkout satisfaction is a satisfaction happened before buying. At this situation, the consumers have tended to compare the service of purchasing system expected with the product they received. But After-delivery satisfaction is a satisfaction after purchasing the product/service. At this situation, the consumers have been comparing the extent to which the seller can fulfill the consumer requirement. Indicators of At-checkout satisfaction and After-delivery satisfaction or overall satisfaction containing as follow: (a) easy to order the products. (b) products information. (c) website performance. (d) products selection. (e) customers service. (f) orders searching. (g) conformity of the products ordered. (h) accuracy of ordering.

\subsection{Convenience}

According to Kwek, et al. [12] convenience is one of the important factors motivating online purchasing. Convenience in this research is referring to the comfortable marketplace access.

According to Oxford Dictionary, convenience is the state of being able to proceed something without facing any difficulties. Internet has made consumers purchase easy to deal with. Because, the consumers are not necessary to face traffic jam, difficult to find parking area, to walk from a shop to another shops. The consumer has stayed just in front of their computer and internet connected.

Referring to Insani \& Prima [8] comfortable is referred to time, space and efforts performed by the consumers.

Referring to Seider written on Insani \& Prima [8] indicators of transaction comfortability refer to easy access, searching, possession, and comfortable transaction accordingly: (a) access convenience has provided the consumers to access the products easily. (b) search convenience is an easy way for the consumers searching the products. (c) possession convenience is an easy way to access and to execute purchasing transaction. (d) transaction convenience is an easy way to purchase and to return the product purchased.

\subsection{Trust}

According to Sumarwan written on Sangadji and Sopiah in Annisa [2], trust is strength of a product which is having a certain attribute. Referring to Iswara [9] customer trust is the main factor to decide purchasing a product.

Referring to Adityo and Khasanah [1], when a person is executing online purchase, the main thing to be considered by the purchaser is whether he/she believes in the website offering online shopping and the online sellers.

According to Kim, written on Sukma [16] Indicators of Trust contain of: (a) satisfaction guarantee. (b) being Concerned. (c) open.

Based on the theories and descriptions above, the hypotheses are as the following:

$\mathrm{H} 1$ : Convenience is affecting positively the purchase decision.

$\mathrm{H} 2$ : Trust is positively affecting the purchase decision.

H3: Convenience is positively affecting the consumer satisfaction.

H4: Trust is positively affecting the consumer satisfaction.

H5: Purchase decision is positively affecting the consumer satisfaction.

H6: Trust is positively affecting the purchase decision thru the purchase decision.

H7: Convenience is positively affecting consumer satisfaction thru the purchase decision

\section{Research Methodology}

\subsection{Population and Samples}

Population of this research are the consumers who have been doing purchasing process using Shopee application living in Bogor area. Total population of this research is unknown, therefore, the extent to which the samples required 
is influenced by total of the statements.

According to Sekaran mentioned on Haryono [7], SEM analysis has required the samples which is at least 5 times of total of indicator variables. Hair et al. [6] recommended size of the samples are about 5 to 20 times of total indicators estimated. This research has applied technique of Maximum Likelihood Estimation (ML). ML technique is effective for about 150-400 samples [7]. In this research, 29 statement items are offered, in order to meet the recommendation of the theories above, total of the samples is 7 time of total of the statements which is $7 \times 29=203$ respondents. After having had the calculation, outlier respondents are produced. However, the related data have to be dropped out or eliminated. Nevertheless, the final samples are 184 respondents.

\subsection{Data Collection Technique}

This research has applied primary and secondary data. Primary data of this research are obtained directly from the resources by distribution the questionnaires to the respondents consisting of the questions related to convenience, trust, purchase decision, and consumer satisfaction. Secondary data of this research are library study, journals, literatures related to the problems and other documentations obtained from online system (internet).

\subsection{Data Analysis Technique}

Data analysis instrument of this research has applied SEM (Structural Equation Modeling) operated using AMOS 23.00 program. Referring to Haryono [7], some steps to be done to analyze the data using SEM. First of all is to produce fit full model to be tested by outlier test, normality test, construct reliability test and validity discriminant

\section{Result and Analysis}

\subsection{Full Model}

Full model in this research is:

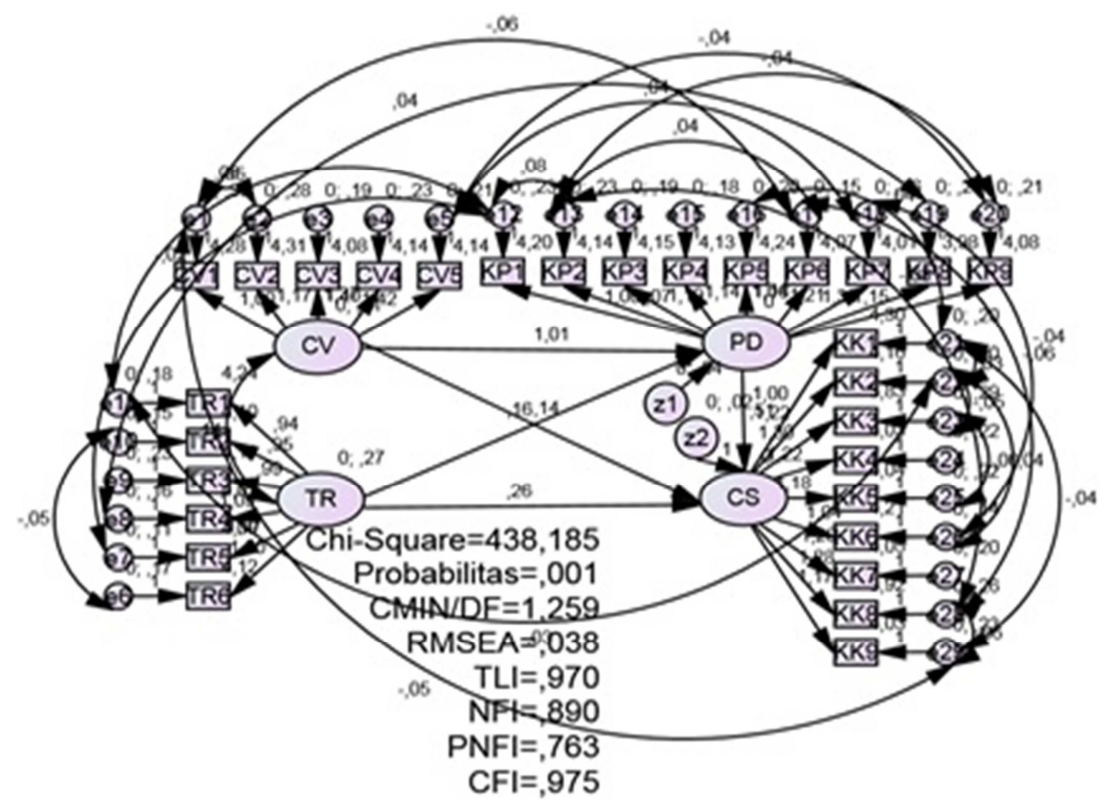

Figure 1. Full Model Research.

Table 1. Regression Weights: (Group number 1 - Default model).

\begin{tabular}{|c|c|c|c|c|c|c|c|}
\hline & & & Estimate & S.E. & C.R. & $\mathbf{P}$ & Label \\
\hline Purchase Decision & $<---$ & Convenience & 1,010 & ,219 & 4,606 & $* * *$ & par_26 \\
\hline Purchase Decision & $<---$ & Trust & ,162 & ,102 & 1,589 & ,112 & par_28 \\
\hline Customer Satisfaction & $<---$ & Convenience & ,141 & ,196 & ,719 & ,472 & par_27 \\
\hline Customer Satisfaction & $<---$ & Trust & ,261 &, 074 & 3,523 & $* * *$ & par_29 \\
\hline Customer Satisfaction & $<---$ & Purchase Decision & ,513 & ,133 & 3,866 & $* * *$ & par 30 \\
\hline
\end{tabular}

Table 2. Standardized Regression Weights: (Group number 1 - Default model).

\begin{tabular}{llll}
\hline & & & Estimate \\
\hline Purchase_Decision & $<---$ & Convenience &, 743 \\
Purchase_Decision & $<---$ & Trust &, 183 \\
Customer_Satisfaction & $<---$ & Convenience &, 112 \\
Customer_Satisfaction & $<---$ & Trust &, 317 \\
Customer_Satisfaction & $<---$ & Purchase_Decision &, 554 \\
\hline
\end{tabular}

Table 3. Squared Multiple Correlations: (Group number 1 - Default model).

\begin{tabular}{ll}
\hline & Estimate \\
\hline Purchase_Decision &, 806 \\
Customer_Satisfaction &, 865 \\
\hline
\end{tabular}

Based on the output of AMOS 23.00 Table 1 on the Regression Weight: (Group number 1-Default model) above 
has indicated that the effect of Trust to Purchase Decision and the effect of Convenience to Consumer Satisfaction are not significant due to value of $C R \leq 1.96$ and $(P) \geq 0.05$. However, the dimension of the effect of Convenience to Purchase Decision, Trust to Consumer Satisfaction, and Purchase Decision to Consumer Satisfaction are significant due to C.R $\geq 1.96$ or probability $(\mathrm{P}) \leq 0.05$. Output of AMOS 23.00 on the Standardized Regression Weights: (Group number 1 - Default model) above has indicated all indicators are valid because they are having standard loading factor of $\geq 0,5$.

The extent to which convenience factor has affected Purchase Decision is $80.6 \%$ and the remaining other factors of $19.4 \%$ has affected Purchase Decision. However, Trust and Purchase Decision have affected $86.5 \%$ of Consumer Satisfaction and the remaining of other factors of $13.5 \%$ has affected Consumers Satisfaction.

Testing hypotheses indirectly, the researcher has applied Sobel Test. And result of the calculation is compared to t-table value. Convenience has affected Consumer Satisfaction thru Purchase Decision significantly, due to t-count $>$ t-table or $2.91867>1.96$ indicating that Purchase Decision is a mediator between Convenience and Consumer Satisfaction which is 0.412. Trust has affected Consumer Satisfaction thru Purchase Decision significantly, due to t-count $<$ t-table or $1.428141<$ 1.96, so that, it is determined that Purchase Decision is not the mediator between Convenience and Consumer Satisfaction.

Structural Equation 1:

$$
\mathrm{PD}=0,743 \mathrm{CV}+0,194
$$

Structural Equation 2:

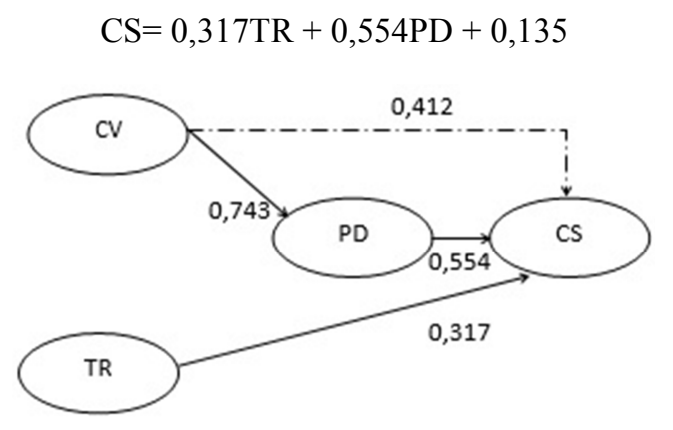

Figure 2. Structural Equation Model.

$\mathrm{CV}=$ Convenience, $\mathrm{TR}=$ Trust, $\mathrm{PD}=$ Purchase Discount, $\mathrm{CS}=$ Customer Satisfaction.

\subsection{Outlier Test}

Degree of freedom or distance mahalanobis value is obtained from indicators total of Full Model. Degree of freedom or distance mahalanobis of 29 indicators at the significant level $\mathrm{P}<0.001$ or $\chi 2(0,001 ; 29)=58,30117$. It has determined that value of $\mathrm{d}$-square of mahalanobis $>58.30117$ which is outlier multivariate that has to be eliminated. But all the value of $\mathrm{d}$-square mahalanobis are under 58.30117. Nevertheless, none of respondent data have to be eliminated but they can continue further test.

\subsection{Normality Test}

Table 4. Assessment of normality (Groupnumber 1).

\begin{tabular}{lccccll}
\hline Variable & $\min$ & $\max$ & skew & c.r. & kurtosis & c.r. \\
\hline Multivariate & & & & & 183,847 & 29,406 \\
\hline
\end{tabular}

Result of Normality test has indicated c.r. value of multivariate of 40.356 which is beyond \pm 2.58 , indicating that the data are not normal multivariate. Therefore, the researcher will try to estimate it using Bootstrap procedure. And after all, output result of Full Model will be compared to the result using Bootstrap procedure.

After comparing SE Bootstrap to SE ML, it will result on average $1 \%$ increasing of parameter comparison. It is indicating that the difference of standard error between before and after bootstrapping is small, and it is determined that having $(\mathrm{N}=184)$ the data has been distributed normal (it is the same with SE Bootstrapping with $\mathrm{N}=500$ ).

\subsection{Construct Reliability Test}

Table 5. Result of Construct Reliability Test.

\begin{tabular}{lllll}
\hline No & Variable & CR & VE & Result \\
\hline 1 & Convenience & 0.7928 & 0.4372 & Reliable \\
2 & Trust & 0.9082 & 0.6231 & Reliable \\
3 & Purchase Decision & 0.9271 & 0.5862 & Reliable \\
4 & Customer Satisfaction & 0.9131 & 0.5387 & Reliable \\
\hline
\end{tabular}

The table above has indicated that all dimensions and indicators of the construct of the research are having the value of standard factor of $\geq 0.5$ indicating that all of them are within good validity. However, variant extracted (VE) of convenience variable indicates the value of 0.4 which is slightly less than recommended value of 0.5 . Nevertheless, in overall, all the variables of this research of Full Model indicated significant reliability and validity.

\subsection{Multicollinearity and Singularity}

Determinant of sample covariance matrix $=, 000$. Output Result of the calculation of sample covariant matrix determinant has indicated 0.000 closed to zero. Though, it is not indicating any multicollinearity and singularity happened in this research, it is still acceptable due to meeting the SEM assumption prerequisite.

\subsection{Discriminant Validity}

Table 6. Result of Discriminant Validity Test.

\begin{tabular}{lllll}
\hline & Convenience & Trust & $\begin{array}{l}\text { Purchase } \\
\text { Decision }\end{array}$ & $\begin{array}{l}\text { Customer } \\
\text { Satisfaction }\end{array}$ \\
\hline Convenience & 0,661 & & & \\
Trust & 0,813 & 0,789 & & \\
$\begin{array}{l}\text { Purchase Decision } \\
\text { Customer }\end{array}$ & 0,743 & 0,183 & 0,765 & \\
Satisfaction & 0,112 & 0,317 & 0,554 & 0,734 \\
\hline
\end{tabular}

Referring to the table above, it has indicated each latent construct having significant discriminant validity, due to each latent construct is having the value which is bigger than the 
correlation value of inter-constructs.

\section{Discussion}

\subsection{The Effect of Convenience to Purchase Decision}

Based on the result of the research, it has indicated significant value of Convenience is near to or same with 0.0000 and critical ratio of 4.606 which is bigger than limited value of 1.967. Coefficient value of structural equation has indicated positive value of 0.743 . Referring to the related result, hypothesis about Convenience has affected positively Purchase Decision is accepted.

Result of this research is in line with the research done by Mahkota et al. [13] with the title of "The Effect of Trust and Comfort to Online Purchase Decision (Case study on the Customers of Website Ride Inc.) indicated that comfort is having positive and significant connection to influence online purchase decision. And the research done by Wardoyo \& Andini [18], with the title of "The Factors influencing Online Purchase Decision of the Students at Gunadarma University", indicated that easy access is having positive and significant influence to online purchase decision.

\subsection{The Effect of Trust to Purchase Decision}

According to the result of the research, Trust has indicated significant value of 0.112 and critical ratio of 1.589 which is less than the limit value of 1.967. Referring to the result above, the hypothesis describing "Trust is not significantly affecting Purchase Decision" is accepted.

The result of this research is in line with the research done by Wardoyo \& Andini [18] with the title of 'The Factors that have affected Online Purchase Decision to the students of Gunadarma" indicated that trust has not significantly affected Online Purchase Decision.

\subsection{The Effect of Convenience to Consumers Satisfaction}

According to the result of the research, Trust has indicated significant value of 0.472 and critical ratio of 0.719 which is less than limited value of 1.967. According to the result above, the hypothesis determining "Convenience is not significantly affecting Consumers Satisfaction" is accepted.

\subsection{The Effect of Trust to Consumer Satisfaction}

Referring to the result of the research, Convenience has indicated significant value near to or equal to 0.0000 and critical ratio of 3.523 which is bigger than limited value of 1.967. Coefficient value of structural equation has indicated positive value of 0.112 . According to the result above, hypothesis determining 'Trust has affected positively Consumer Satisfaction' is accepted.

This result is in line with the research done by Dewi, et.al. [4] with the title of "The Effect of Product Quality and Trust to Purchase Decision and Consumer Satisfaction as intervening variable" described that Trust has indicated positive and significant correlation with Consumers Satisfaction.

\subsection{The Effect of Purchase Decision to Consumer Satisfaction}

Result of the research has indicated significant value of Purchase Decision near to or equal to 0.000 and critical ratio of 3.866 which is bigger than the limited value of 1.967 . Coefficient value of structural equation is having positive value of 0.554 . According to the result above, hypothesis determining 'Purchase Decision has positively affected Consumers Satisfaction' is accepted. Result of this research is in line with the research done by Dewi et al. [4] with the title of "The Effect of Product Quality and Trust to Purchase Decision and Consumer Satisfaction as intervening variable" described that Consumer Decision has positively and significantly correlated with Consumers Satisfaction.

\subsection{The Effect of Convenience to Consumer Satisfaction thru Purchase Decision}

Result of the research has indicated that Convenience is having t-count value of 2.91867 which is bigger than $t$-table of 1.967. And Coefficient value of structural equation is having positive value of 0.412 . According to this result, hypothesis describing 'Convenience has positively affected Consumers Satisfaction thru Purchase Decision' is accepted.

Result of this research is in line with the research done by Damasta \& Widayanto [3] with the title of "The Effect of easy Transaction and Shopping Convenience to Customer Satisfaction thru Purchase Decision about Online Shopping Transaction (study to the students of FISIP Undip assessor Lazada.co.id webs)" indicated that Convenience has positively and significantly affected Consumer Satisfaction thru Purchase Decision.

\subsection{The Effect of Trust to Consumer Satisfaction thru Purchase Decision}

Result of the research has indicated that Convenience has had t-count value of 1.428141 which is less than t-table value of 1.967. According to this result, the hypothesis describing 'Trust is not affecting significantly Consumer Satisfaction thru Purchase Decision' is accepted.

\section{Conclusion and Suggestion}

\subsection{Conclusion}

According to the result of analysis, here are the following conclusion: (a) convenience has positively and significantly affected purchase decision. This conclusion is referred to C.R value of $4.606>1.967$ or indicating $* * *$ signs on $p$ value. (b) trust has not significantly affected purchase decision. This conclusion is referred to C.R value of $1.589<1.967$ or 0.112 of $p$ value. (c) convenience has not significantly affected consumer satisfaction. This conclusion is referred to C.R value of $0.719<1.967$ or 0.472 of $p$ value. (d) trust has positively and significantly affected consumer satisfaction. This conclusion refers to C.R value of 3.523 $>1.967$ or indicating $* * *$ signs on $p$ value. (e) purchase decision has positively and significantly 
affected consumer satisfaction. This conclusion refers to C.R value of $3.866>1.967$ or indicating $* * *$ signs on $\mathrm{p}$ value. (f) purchase decision has mediated convenience and consumer satisfaction. This conclusion refers to $t$-count value $>\mathrm{t}$-table (2.91867>1.96). (g) purchase decision has not mediated trust and consumer satisfaction. This conclusion refers to $\mathrm{t}$-count $<\mathrm{t}$-table $(1.428141<1.96)$.

\subsection{Suggestion}

Referring to the result of the research, description and conclusion above, some suggestions could be offered as follows: (a) Shopee concerned, according to the respondent responses on this research, some efforts should have to be done by Shoppe, as the following: (1) in this research, Convenience is consisting of the dimension of comfortable access, comfortable searching, possession and comfortable transaction that are necessary to be improved such as easier access, so that consumer can do it anywhere either using devise application or Shopee website to make consumer easy and comfort to execute purchasing. (2) in this research, Trust consists of the dimension of satisfaction guarantee, clear and being concerned are necessary to be improved referring to clear information provided by Shopee about promotion offered and information about the product sold by Shoppe, in order to make customers satisfied with Shopee marketplace. (3) in this research, Purchase Decision consists of the dimension of requirement, benefit, delivery on time, and repeat purchasing will affect consumer satisfaction on Shopee Marketplace. Shopee is expected to improve the products variation to increase Purchase Decision affecting Consumer Satisfaction. (b) future researchers concerned. Next researchers can develop the research using convenience dimensions which could affect Purchase Decision. The extent to which convenience factors affecting Purchase Decision is $80.6 \%$ and $19.4 \%$ of other factors. Next research can analyze more concern about each dimension such as comfort access, comfort searching, possession convenience, and comfort transaction.

Next researchers are able to expand this research by doing more concern about the trust variable and purchase decision variable which could affect consumer satisfaction. The extent to which factors of trust and purchase decision affecting consumer satisfaction is $86.5 \%$ and other factors is $13.5 \%$. Next researchers are able to analyze more concern about each variable. In spite of that, other dependent variables are necessary to be included such as repeat purchase or consumers loyal.

\section{References}

[1] Adityo, B \& Khasanah, I. (2010). Analisis pengaruh kepercayaan, kemudahan dan kualitas informasi terhadap keputusan pembelian secara on line di situs KASKUS. Jurnal Skripsi Universitas Diponegoro.

[2] Annisa, D. (2019). Pengaruh Kepercayaan, Kemudahan, dan Kualitas Informasi Terhadap Keputusan Pembelia Online Melalui Aplikasi Shopee (Studi Kasus Pada Mahasiswa Ilmu
Komunikasi Universita Mulawarman 2015 - 2017). Jurnal Administrasi Bisnis ISSN 2355-5408. Samarinda: UNMUL

[3] Damasta, M. I \& Widayanto. (2018). Pengaruh Kemudahan Transaksi dan Shopping Convenience Terhadap Customer Satisfaction Melalui Keputusan Pembelian Dalam Transaksi Belanja Online (Studi pada Mahasiswa FISIP Undip Pengakses Situs Lazada.co.id). Jurnal Ilmu Administrasi Bisnis, 7 (4), 1-8. https://ejournal3.undip.ac.id/index.php/jiab/article/view/21919 $/ 20175$

[4] Dewi, W. S., Hasiolan, L. B. \& Minarsih, M. M. (2016). Pengaruh Kualitas Produk, Kepercayaan tehadap Keputusan Pembelin Dengan Kepuasan Konsumen Sebagai Variabel Intervening. Journal of Management, 2 (2).

[5] Djan, I \& Burhanudin, C. (2006). Analisis Hubungan Antara Merek Semen Dengan Tingkat Kepuasan Konsumen di Kecamatan Citeureup. Jurnal Ilmiah Binaniaga. Vol, 2. No, 2. (Analysis of the Correlation between Cement Branded and the Level of Consumer Satisfaction at Citeureup Subdistrict. Jurnal Ilmiah Binaniaga, 2 (2).

[6] Hair, J. F., Black, W. C., Babin, B. J. \& Anderrson, R. E. (2010). Multivariate Data Analysis. New Jersey: Pearson Education.

[7] Haryono, S. (2017). Metode SEM Untuk Penelitian Manajemen. Jakarta: Luxima (SEM method for Management Research, Jakarta-Luxima).

[8] Insani, E. P. (2013). Anlisis Pengaruh Kenyamanan Terhadap Minat Beli Secara Online Pada Pemesanan Tiket Kereta Api Melalui Website Resmi PT KAI. Jurnal Sains Pemasaran $\begin{array}{llll}\text { Indonesia } & 12 & \text { (3), } & \text { 241-260. }\end{array}$ https://doi.org/10.14710/jspi.v12i3.241-260

[9] Iswara, D. (2016). Pengaruh Kepercayaam, Kemudahan, Kualitas Informasi, dan Presepsi RISIKO Terhadap Keputusan Pembelian (Studi Kasus Pada Pengguna Media Sosial Instagram Di Kota Yogyakarta. Yogyakarta: UNY.

[10] Kotler, P \& Keller, K. L. (2016). Manajemen Pemasaran, Jakarta: Penerbit Erlangga.

[11] Kurniawati, N. \& Puniawan, I. M. (2017). Pengaruh Kepuasan Konsumen Terhadap Keputusan Berbelanja Online Kembali. Jurnal Prosding Seminar Nasional Hasil Penelitian.

[12] Kwek, C., Tan, H \& Lau, T. C. (2010). Investigating the Shopping Orientations on Online Purchase Intention in the e-Commerce Environment: A Malaysian Study. Journal of Internet Banking and Commerce, 15 (2), 1-22. http://www.arraydev.com/commerce/jibc/

[13] Mahkota, A. P., Suyadi, I., \& Riyadi. (2014). Pengaruh kepercayaan dan kenyamanan terhadap keputusan pembelian online (Studi pada Pelanggan Website Ride Inc). Jurnal Administrasi Bisnis, 8 (2).

[14] Mujiyana, M., \& Elissa, I. (2016). Analisis Faktor-faktor Yang Mempengaruhi Keputusan Pembelian Via Internet Pada Toko Online. JTI UNDIP: Jurnal Teknik Industri, 8 (3). https://doi.org/10.12777/jati.8.3.143-152.

[15] Permatasari, E. N. (2017). Pengaruh kualitas pelayanan, persepsi harga dan lokasi terhadap keputusan pembelian pada pelanggan minimarket: Studi Kasus pada Pelanggan Minimarket Alfamart Tayu Wetan, Tayu, Pati, Jawa Tengah [Undergraduate Thesis, Universitas Negeri Yogyakarta]. https://eprints.uny.ac.id/54142/1/ElienNiraPermatasari_15808 147012.pdf 
[16] Sukma, A. A. (2012). Analisis Faktor-Faktor Yang Mempengaruhi Keputusan Pembelian Melalui Social Networking Websites. Jurnal Ekonomi Manajemen, 1-11.

[17] Tjiptono, F. (2008). Strategi Pemasaran. Yogyakarta: Andi. (Marketing Strategy, edition $3^{\text {rd }}$, Yogyakarta. Andi)
[18] Wardoyo, \& Andini, I. (2017). Faktor-Faktor Yang Berpengaruh Terhadap Keputusan Pembelian Secara Online Pada Mahasiswa Universitas Gunadarma. Jurnal Ekonomi Manajemen Sumber Daya, 19 (1), 12-26. 